\title{
Application and Comparison of Analytical Hierarchy Process (AHP) and Network Methods in Path Finding of Pipeline Water Transmission System, from Taleghan's Dam to Hashtgerd New City, Tehran, Iran
}

\author{
M. Arabi, Saeid Gharehhassanloo* \\ Faculty of Civil Engineering, Shahid Rajaee Teacher Training University (SRTTU), Tehran, Iran \\ Email: Arabi350@yahoo.com, *saeidgharehhassanloo@gmail.com
}

How to cite this paper: Arabi, M. and Gharehhassanloo, S. (2018) Application and Comparison of Analytical Hierarchy Process (AHP) and Network Methods in Path Finding of Pipeline Water Transmission System, from Taleghan's Dam to Hashtgerd New City, Tehran, Iran. Open Access Library Journal, 5: e4303.

https://doi.org/10.4236/oalib.1104303

Received: January 3, 2018

Accepted: April 14, 2018

Published: April 17, 2018

Copyright $\odot 2018$ by authors and Open Access Library Inc.

This work is licensed under the Creative Commons Attribution International License (CC BY 4.0).

http://creativecommons.org/licenses/by/4.0/

\begin{abstract}
These instructions give you guidelines for preparing determination of optimum path by considering technical and engineering, environment and cost management visions. In this point of view from Taleghan's dam to Hashtgerd New City case study, we need to distinguish and apply the essential parameters such as topographic and morphologic conditions, environmental issues by consideration on sustainable development, population distribution patterns, roads and etc. by using base map and extraction of expected points geometrical location from Google Earth, position land surveying done. Then the mentioned co-parameters data layer loaded in GIS environment and after allocation the special coefficient and value for weighting parameters and combine them based on MCE method and the cost map made based on AHP method which Lead to determination of optimum path by using LCPA method. Paths include of ABFA path and two evaluated optimum path compared and indicated that two optimum paths overlapped mostly. Cost comparison between optimum path and ABFA path imply $14 \%$ decrease in expenditure Which the main extra expense of ABFA path due to more intersection with rivers, roads and necessity construct of structures to keep water natural regimes, passing unauthorized areas and personal parcels need to pay, path finding only by personal experience underestimating academic science, data analyzing software's which Cause to increasing the length of water supply pipeline.
\end{abstract}

\section{Subject Areas}

Civil Engineering 


\section{Keywords}

Weighting, Water Pipeline, Taleghan Dam, Hashtgerd New City, Analytical Hierarchy Process, Optimum Path

\section{Introduction}

Initial design of path and phase zero study, is one of the most important steps in construction of the pipelines in before construction starting from different aspects investigated and safest and most economical location of path construction recognized [1]. Processing and analysis to determine shortest path always has been one of the most applied ways. At the moment, different algorithm for optimum path finding according to effective parameters and their different particulars are presented. Which one of evaluation methods and analysis of geographical balance, spatial and temporal has an influence basis parameter, it is important that needs to techniques applied and special methods; optimization, is an important activity and determining in design. When designer will be able to generate better schemes, they can economize by using optimization methods in time and cost design. Due to numerous limitations and problems in implementing pipelines' pipelines, scientific-based routing, with the aim of optimizing, finds the best route economically "cheap and affordable" in terms of distance "shorter" and in terms of "low risk" safety, has found a special place and has attracted the opinion of most contractor companies. For solving problem, maybe there have been several procedures that to compare them and choose the optimal solution, the objective function is defined and chooses this function depend on nature of the problem [2]. For example, deduction of the time or cost is common purpose of optimization for path finding water pipeline. In designing the path, in addition to consideration technical epigram and economic, we should also pay attention to environmental particulars which cause minimum environmental damage.

\section{Helpful Hints}

Over two decades paid attention to GIS software ability in path designing such as road, rail way, oil and gas and water transition pipelines telecomunation cables and so on.

In the case of finding optimum path for pipeline by using GIS, several multiple project done in the world wide but in Iran country lack of GIS ability knowledge cause to ignoring GIS in the project's design phase.

1) Naghibi on 2002 in Tehran university investigate the part of oil and gas transition pipelines of Ahvaz-Maroon axis by using GIS; At the end he concludes that constructed path $29 \%$ more expensive than designed path by software which technical and bio-economical impacts considered [3].

2) Shoubiri et al., on 2015 performed optimum path finding of water transition 
pipeline by using DEM (Digital Elevation Model) and GIs tools. In this research by DEM obtained from satellite and GIS used for reaching optimum path. Base of this purpose major criteria listed and valued each criterion by expert and all the layers matched corresponds to their values and after all the optimum path revealed. The proposed path by the GIS possess benefits such as higher technical value and shorter pipelines length rather than built pipeline path [4].

3) Yildrirm and tomuralioglu on 2011 comparing the path finding method for oil and gas pipelines traditional procedure. In this research prove that the path which designed by using GIS $14 \%$ cheaper than the path with traditional procedure and even though GIS software is more user friend than other softwares. Also GIS giving us both conceptual model and real model correspond to topographic terrain. By using this system most of main aspects such as effective parameters on pipelines path finding determined. Furthermore, for assigning value of each parameters used AHP (Analytical Hierarchy process) method [5].

4) Balogoun et al., on 2012 perform research with title of choosing optimum path of oil and gas pipelines using by GIS. In this research the value of variables depends on amount of importance these variables for society. They evaluate valued variables based on the amount of vulnerability for ecological habitat and finally the proposed method concludes to less environmental hazard [6].

The result come from mentioned researches validated the GIS ability on automatically path determination and also he experiential results imply that final output of perform to optimal output. Noticeable point, detecting the effective parameters correspond to purpose of project, the area conditions and also relative values for them which better to consider experts' suggestion.

The final purpose of this research, the participation of effective parameters by using GIS, LCPA (Least Cost Path Algorithm) and MCE (Multi-Criteria Evaluation) method on determination of optimum path and also compare optimum path with constructed path by the Alborz province water and wastewater company point of view technical and engineering, cost management and bio-ecological.

\section{Overview of Path Finding Theories Experts in World Are Three Categories}

1) The first group believe to economic views that deduction of time, cost and path are very important for them.

2) Another group believe to environmental views that they emphasize to deduction of environmental hazards (a) Environment factors b) Ecological factors c) Human factors).

3) Consolidated views that includes two preceding views is new theory and views on the world that it is used in this investigation and according to this views to some theories related to the path finding in this investigation will be discussed. The theories include of: 
In modern age growth of cities will likewise increase the demand for water pipelines. Pipelines are by far the most economical, practical and safe option of fluid transport. An important problem in pipeline is the path finding assignment [7].

Traditional method of optimum path in pipelines are mainly based on expensive and protected methods. These methods are not precise and the role of all effective parameters in pipeline path finding cannot be easily considered. Most technical, economical and environmental concerns are not observed in designed path. Meanwhile GIS, remote sensing and intelligent methods are efficient tools for decision making and consultation for experts in pipeline design ([8] [9]).

The GIS, as a new technique for collection and analysis pf spatial data, together with genetic algorithm as one of the most important evolutionary algorithms with features like flexibility, robustness and consistency in solving the complicated problems have important functions. So, combination of information from satellite images, object-oriented programming, available GIS techniques and genetic algorithm can lead to more accurate results in shorter time [10].

Thus, selecting a suitable path to avoid existing obstacles not only reduces the risk of damaging existing utilities, but also minimizes the cost and duration required for construction. The GIS helps planners identify the spatial relationships between different data layers. In addition, GIS not only stores the spatial features and attributes, but can also be used as an analysis tool [11].

A GIS usually provides a number of tools for the analysis of spatial networks. It generally offers tools to find the shortest or minimum path [12].

Various investigations have been performed for using genetic algorithm in path finding problems optimization [13].

Careful planning of their path can save on cost, time and operating expenses, ensure longer operational life and help prevent environmental fallouts. So, it is clear that more efficient methods for path design are required ([14] [15] [16]).

The path finding technique used for calculating shortest path, cost reductions reported by the companies was typically between $10 \%$ and $20 \%$ [17].

\section{Range and Areas of Research}

Taleghan small town locate 100 kilometers northwest of Tehran and between grand valley the Alborz mountains and Hashtgerd New City from geographically in west Tehran province at an altitude of 1310 to 1610 meters above sea level. The study area is between latitudinal $36^{\circ} 12^{\prime}$ to longitudinal $50^{\circ} 47^{\prime}$ and latitudinal $50^{\circ} 25^{\prime}$ to longitudinal $50^{\circ} 55^{\prime}$ and latitudinal $35^{\circ} 45^{\prime}$ to longitudinal $36^{\circ} 5^{\prime}$ (Figure 1) $[18]$.

\section{Research Procedure}

This research is type of applied-analytical that first understudied library and documents studies and dispose of expert's sessions for doing work, theory framework and path features. Then by using observation and field in investigations, relate existing maps and receive data in softwares environment such as 


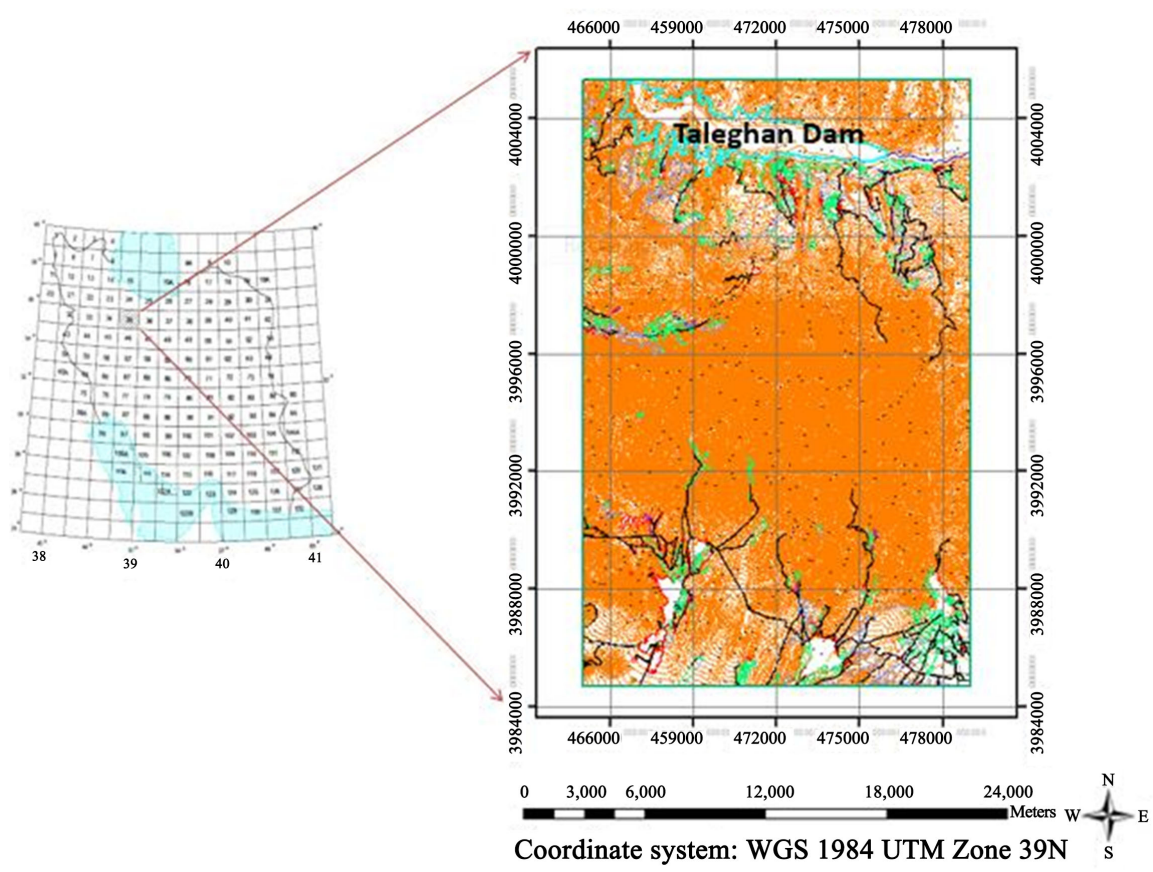

Figure 1. The study area.

ArcGIS and IDRISI Selva, with due to condition interpret them. Finally, by allocating values to model, necessary tests, evaluated and validated of results, optimum path determine. So, recommendations based on research obtaining for study subject will present (Figure 2).

\section{The Aspects of Research}

1) Effective criteria in path finding water transition pipelines;

The multi-criteria evaluation to achieve a certain goal, you need to define measures or indicators which based on them achieve to certain goal. These measures and indicators call evaluation criteria [19]. Which in further classified into categories: factors and constraints [20]. Essentially, principles and criterias that have been considered in this study are dividing two categories: socio-economical and ecological criterias which the criterias choose according to rules environmental prescription. The ecological criteria include of: slope and height and socio-economical criteria include of: land use, urban region and rural, access roads and infrastructure. The by using the Table 1, map's criterias and constraints are extracted.

2) Path finding by using the lowest cost path algorithm in ArcGIS:

Finding optimized path by using LCPA in ArcGIS depends on point of origin and destination, cost map and accumulative cost map. ArcGIS software to calculate the shortest path first by cost map, point of origin and cost distance tool, cost surface in order to calculate cost of moving from origin to destination acquires and accumulative value of each cell and after accumulative cost map production, the optimum path from point of origin determine. 


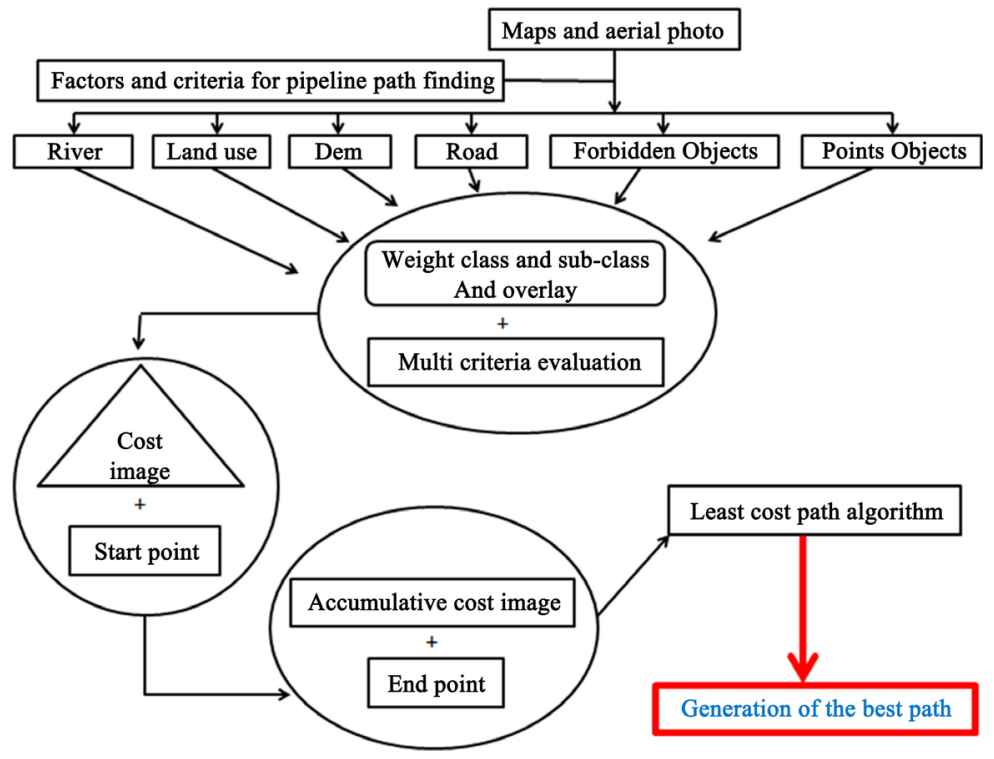

Figure 2. Overview of implementation steps and analysis results.

Table 1. The layers used in the path finding process.

\begin{tabular}{|c|c|c|c|}
\hline Reference & Description & Information & Criteria \\
\hline $\begin{array}{l}\text { National mapping } \\
\text { organization }\end{array}$ & $\begin{array}{l}\text { Include of permanent and } \\
\text { seasonal rivers in the region }\end{array}$ & Rivers map & \\
\hline $\begin{array}{l}\text { National mapping } \\
\text { organization }\end{array}$ & $\begin{array}{l}\text { Include of elevation data } \\
\text { which have made from region } \\
\text { topographic map }\end{array}$ & $\begin{array}{l}\text { Digital elevation } \\
\text { model map }\end{array}$ & Ecological criterias \\
\hline $\begin{array}{l}\text { National mapping } \\
\text { organization }\end{array}$ & $\begin{array}{l}\text { It have made from digital } \\
\text { elevation model }\end{array}$ & Slope map & \\
\hline $\begin{array}{l}\text { National mapping } \\
\text { organization }\end{array}$ & $\begin{array}{l}\text { Include of major and minor } \\
\text { road }\end{array}$ & Road map & \\
\hline $\begin{array}{l}\text { National mapping } \\
\text { organization }\end{array}$ & Represent residential spots & $\begin{array}{l}\text { Urban and rural } \\
\text { region }\end{array}$ & $\begin{array}{l}\text { Socio-economical } \\
\text { criterias }\end{array}$ \\
\hline $\begin{array}{l}\text { National mapping } \\
\text { organization }\end{array}$ & $\begin{array}{l}\text { Include of installation of } \\
\text { welfare, centers } \\
\text { (cultural-religious) and so on }\end{array}$ & Infrastructures map & \\
\hline
\end{tabular}

a) Process of determining the optimum path by using Analytical Hierarchy process include of [21]:

i) Weighting factors: Weight and relative importance of each factors must be determined in relation to the intended target. Since role and importance of each criterion in determining path are not same and in other words, limit factors in determining path are not same and some of characteristics, act as key factors [22]. Hence, these elements weighted and evaluated. So at this stage dataset must be weighted and combined and according to Table 2, their influence had been stopped in the analysis. Thus, according to experts of Alborz province water and wastewater suggestion about slope which has a significant impact in the region, considered to be highest percentage. Next to valuation data collection question- 
naire in the frame of weighting effective parameters in determining optimum path based on input from 40 experts and Alborz province to provide water and sanitation experts, that after these two ideas, data collection according to Tables 3-5 are evaluated on the basis of AHP. In Tables 3-5, coefficient of 1 has least cost and coefficient of 10 has highest cost for cross from obstacles and for absolute obstacles (mosque, cemetery, building and so on) that don't allow crossing of them, coefficient of 10 mentioned.

Table 2. Effect of factors in determining the optimum path.

\begin{tabular}{cc}
\hline Factors & The effect percent of factors \\
\hline Slope & 50 \\
Land use & 30 \\
Linear objects & 20 \\
\hline
\end{tabular}

Table 3. Weight of existing land use in the study area.

\begin{tabular}{lcc}
\hline \multicolumn{1}{c}{ Reason given coefficient } & $\begin{array}{c}\text { Weight coefficient } \\
(1-10)\end{array}$ & Object \\
\hline $\begin{array}{l}\text { Personal property+ environmental damages + } \\
\text { garden destruction + cost of ownership }\end{array}$ & 9 & Garden \\
$\begin{array}{l}\text { Personal property + environmental damages + } \\
\text { vineyard destruction + cost of ownership }\end{array}$ & 9 & Bare land \\
$\begin{array}{l}\text { Personal property + environmental damages + } \\
\text { bare land destruction + cost of ownership }\end{array}$ & 2 & Agriculture \\
$\begin{array}{l}\text { Personal property + environmental damages + } \\
\text { agriculture destruction }+ \text { cost of ownership }\end{array}$ & 8 & \\
\hline
\end{tabular}

Table 4. Weight of existing linear objects in the study area.

\begin{tabular}{|c|c|c|}
\hline Reason given coefficient & $\begin{array}{l}\text { Weight } \\
\text { coefficient } \\
(1-10)\end{array}$ & Object \\
\hline $\begin{array}{l}\text { The high costs and official problems in the } \\
\text { municipality and urban planning+ high execute } \\
\text { costs+ increasing risk of rapture due to heavy traffic } \\
\text { vehicles (pressure external load)+ high cost of urban } \\
\text { taxes+ traffic }\end{array}$ & 9 & First class road \\
\hline $\begin{array}{l}\text { High cost of urban taxes }+ \text { traffic }+ \text { high pressure } \\
\text { passage of vehicles }\end{array}$ & 8 & Second class road \\
\hline $\begin{array}{l}\text { High cost of urban taxes }+ \text { traffic }+ \text { high pressure } \\
\text { passage of vehicles }\end{array}$ & 7 & Third class road \\
\hline Urban taxes & 5 & Fourth class road \\
\hline Urban taxes & 4 & Fifth class road \\
\hline $\begin{array}{l}\text { Bridge construction cost+ environment destruction+ } \\
\text { consider river natural regime and ground water }\end{array}$ & 9 & River \\
\hline
\end{tabular}


Table 5. Weight of existing slope in the study area

\begin{tabular}{|c|c|c|}
\hline slope & $\begin{array}{c}\text { Weight } \\
\text { coefficient } \\
(1-10)\end{array}$ & Reason given coefficient \\
\hline $0.000247-7.959794$ & 4 & $\begin{array}{l}\text { For supply pressure into the transition pipeline need to } \\
\text { cost }+ \text { because of low or zero slope and water low } \\
\text { speed and could flow fluently possible to sediment into } \\
\text { the pipe + sedimentation path and water low speed } \\
\text { (drop water speed cause of friction) + necessity for } \\
\text { pumping water + cost of constructing pumpage station } \\
\text { (external cost of electricity supply and so on) }\end{array}$ \\
\hline $7.959794-15.919342$ & 3 & $\begin{array}{l}\text { For supply pressure into the transition pipeline need to } \\
\text { cost }+ \text { erosion of pipe }\end{array}$ \\
\hline $15.919342-23.878889$ & 4 & $\begin{array}{l}\text { For supply pressure into the transition pipeline need } \\
\text { to cost }+ \text { increase friction coefficient of pipe }\end{array}$ \\
\hline $23.878889-31.838436$ & 4 & $\begin{array}{l}\text { For supply pressure into the transition pipeline need } \\
\text { to cost }+ \text { increase friction coefficient of pipe }\end{array}$ \\
\hline $31.838436-39.797983$ & 5 & Erosion of pipe \\
\hline $39.797983-47.75753$ & 6 & Erosion of pipe \\
\hline $47.75753-55.717077$ & 7 & Erosion of pipe \\
\hline $55.717077-63.676624$ & 8 & Erosion of pipe \\
\hline $63.676624-71.696171$ & 10 & Impossible \\
\hline $71.696171-79.595718$ & 10 & Impossible \\
\hline
\end{tabular}

ii) Create cost surface or friction: Purpose of this stage, produced a data layer in interlace format raster all cells move and pass costs can be attributes and this layer is called cost surface or friction. Taken together, the opinions of experts and specialists Alborz province water and wastewater company, weighting coefficient of effective parameters in determining the optimum path, dataset valued and by using weighted data, cost map as shown in Figure 3 produce.

iii) Create accumulative cost surface: To generate this level as seen in Figure 3 and Figure 4 requires a level called weighting surface (or friction surface) and one or more points as the source or starting points. The friction surface, cost of moving from one cell to another based on distance, time, cost and so on. In this study, expense is based on cost.

iv) Integration of maps and producing the final map: One of important parts of the regional analysis, the combination of data and information to create maps, layers and new data which shown in Figure 5. On this basis, the weighted raster maps generated and all of them are displayed in ArcGIS. These maps were combined and ultimate map correspond to final weight produced.

3) Path finding in network GIS

Path finding algorithm in raster model, similar to operating algorithm in the vector model. But direction modeling in raster network rather than vector network is not simply but possible. To find the path of least cost must be on a level with the accumulative costs, to move on the cost values must combine a variety of different cells that is a bit complicated [23]. After the accumulated cost pro- 
duce, path finding function of endpoint, search has begun and using a window of $3 \times 3$, neighbors around each pixel is searching and pixel which has least accumulated cost as selecting move and so on, for repented path finding process continues to be the path state point [24].
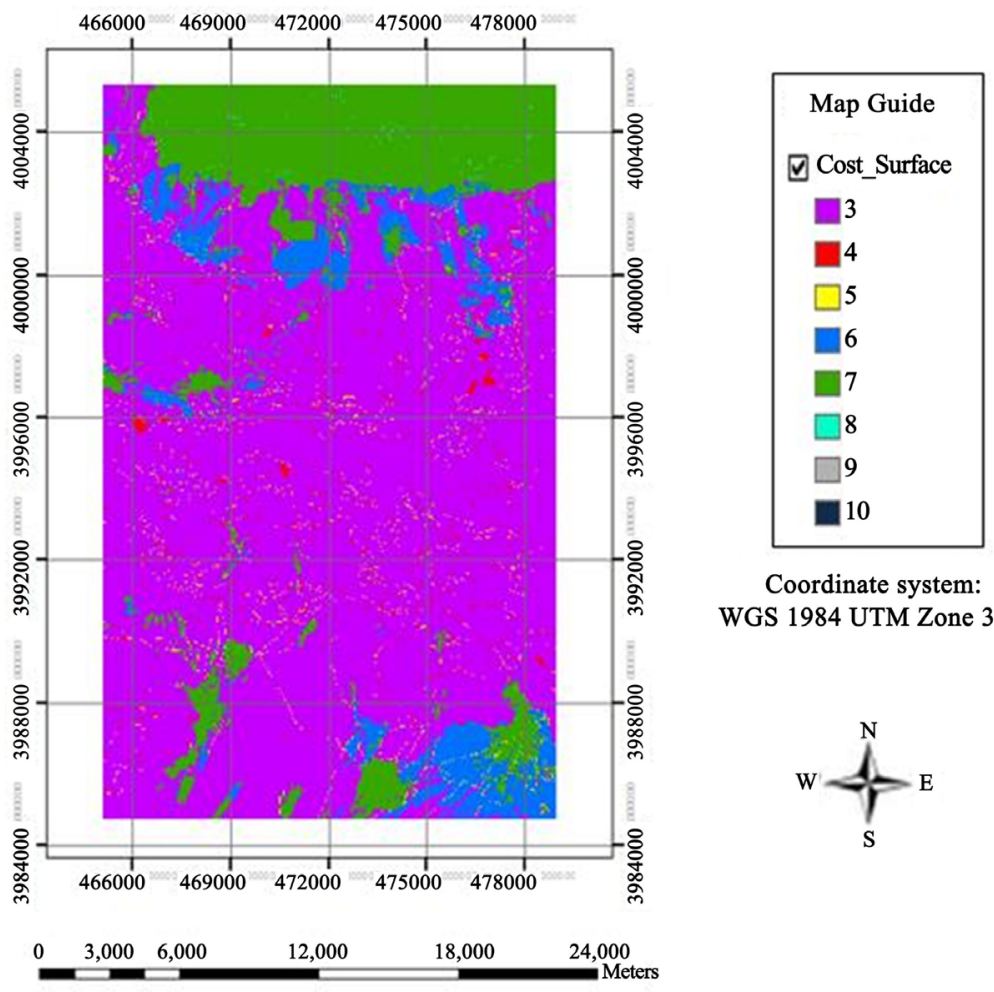

Coordinate system:

WGS 1984 UTM Zone 39N

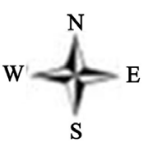

Figure 3. Cost surface map of the study area.

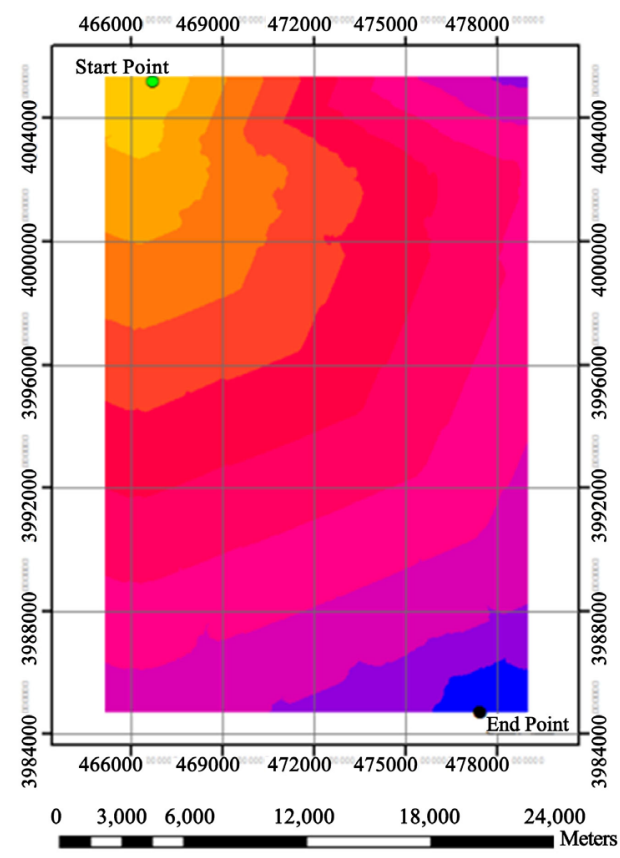

\section{Map Guide}

$\square$ Accumulated cost surface $\square 0-8,526.346094$

$\square 8,526.346095-17,052.69219$

$17,052.6922-25,579.03828$

$\square 25,579.03829-34,105.38438$

- $34,105.38439$ - 42,631.73047

- $42,631.73048$ - $51,158.07656$

-51,158.07657 - 59,684.42266

$59,684.42267-68,210.76875$

따,210.76876 - 76,737.11484

- $76,737.11485-85,263.46094$

Coordinate system:

WGS 1984 UTM Zone 39N<smiles>[Y1]C1CC(N)=C1F</smiles>

Figure 4. Accumulative cost surface of the study area. 


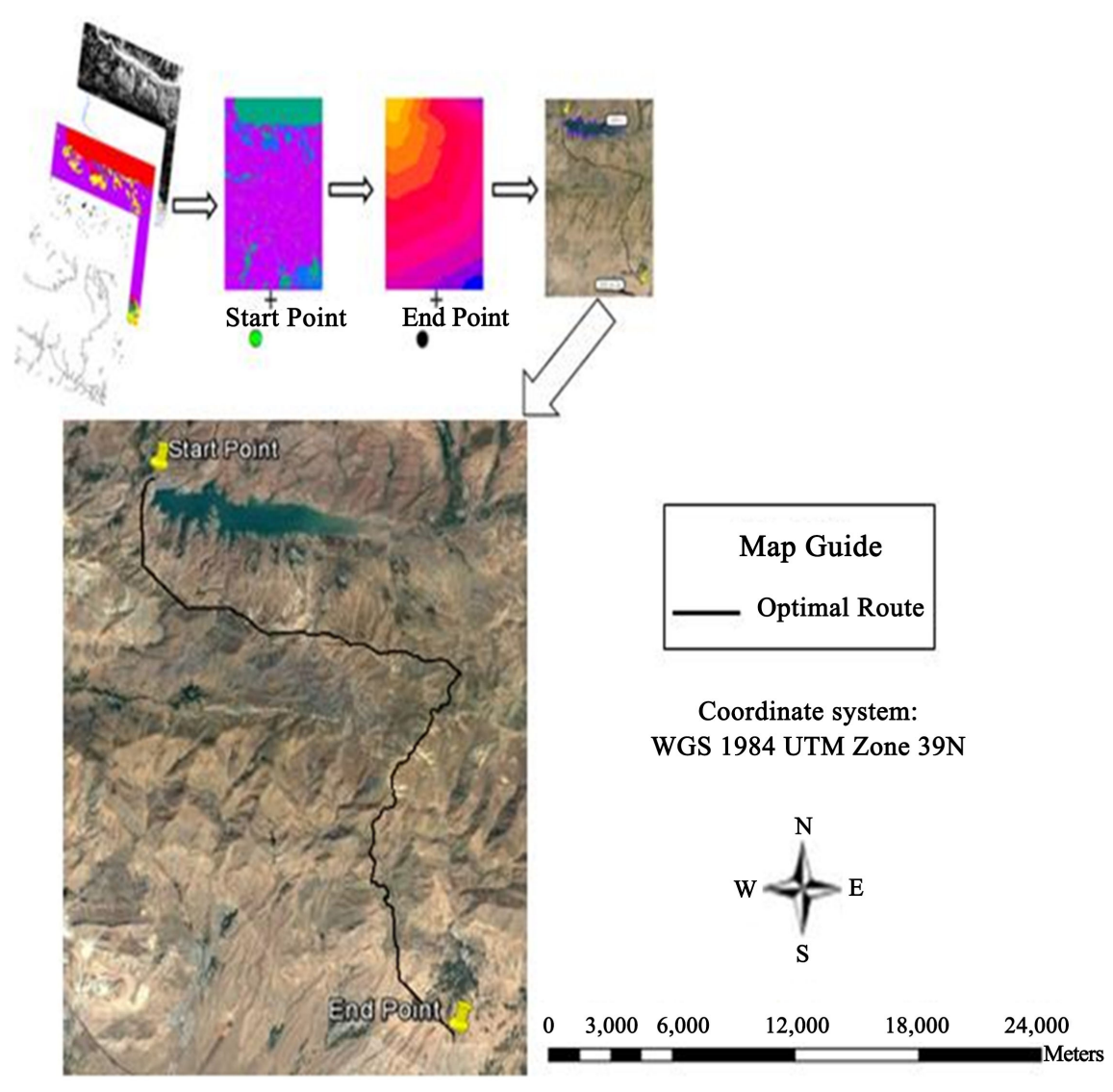

Figure 5. The final map of the optimum path pipelines from taleghan's dam to hashtgerd new city.

Process of determining the optimum path in network GIS include of:

i) Create cost surface or friction: How formed these levels depends on criteria used in determining the path. Cell units of this level can cost, time, distance and so on. But the important problem, resistance of each cells determined by value allocated [10]. The purpose of this stage, produced a data layer lattice format raster to all cells move and pass those costs have been attributed and this layer, called the cost surface or friction surface. In this layer, each pixel represents a resistance value or cost per pixel to pixel source in Figure 6 is much larger this value, represents more friction to cross the cell's path.

ii) Create accumulated cost surface: The accumulative cost of the function rather than the actual distance between two points is calculated, weighted distance between them can be considered and how their actions is as follow that each cell on a primary network which amount of costs or cells show resistance movement, as see in Figure 6 and Figure 7, it returns a point as a point source and a cost level as its input and the network creates an output that each cell of the network, indicating the cost of the unit cells and cells of the network resource, not a single geometric, but is unit, moving the unit cost [25]. In this layer, each pixel value represents the sum of the cost or value between given pixel and primary pixel which higher value pixel, this means that pixel is less credible to pass through. 

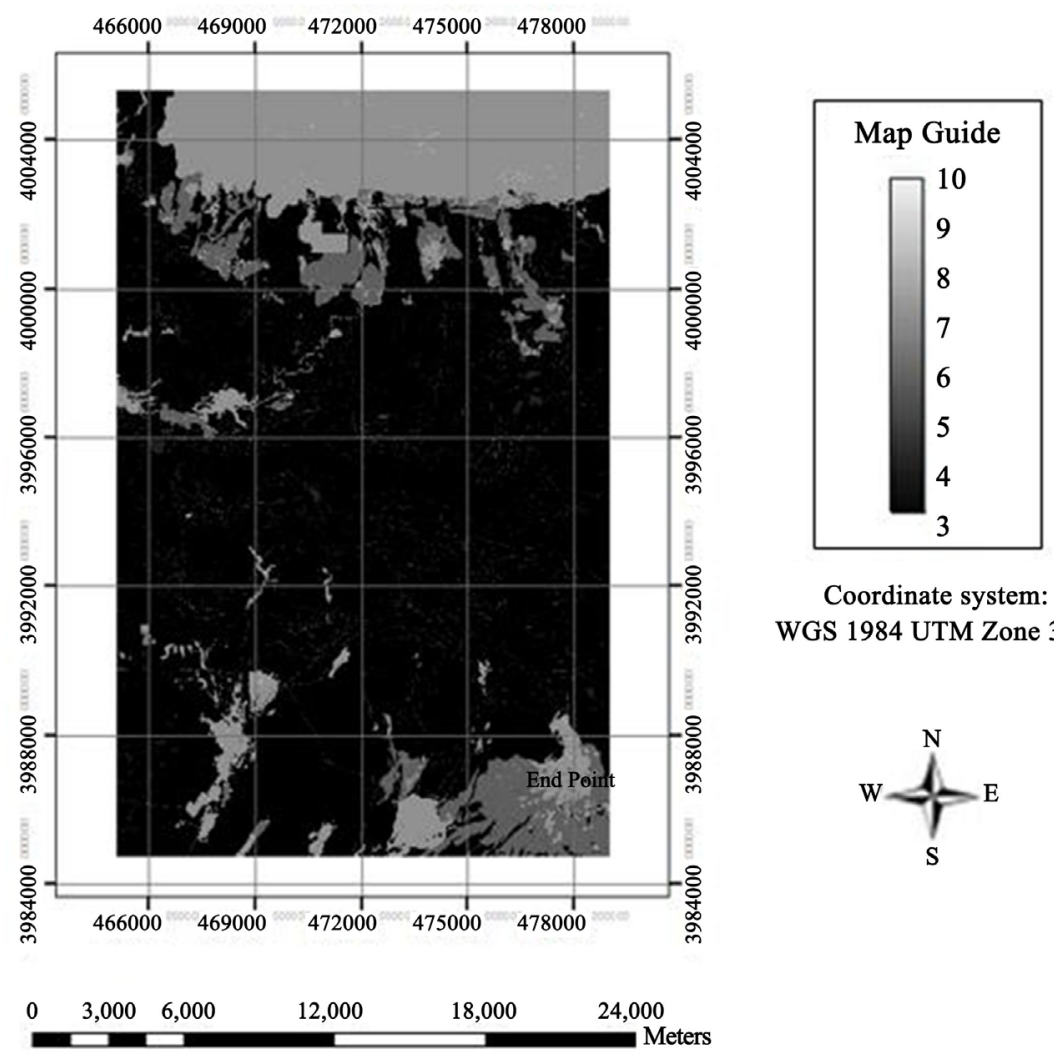

Coordinate system: WGS 1984 UTM Zone 39N<smiles>[Y]C1CC(N)=C1P</smiles>

Figure 6. Cost surface map of the study area.
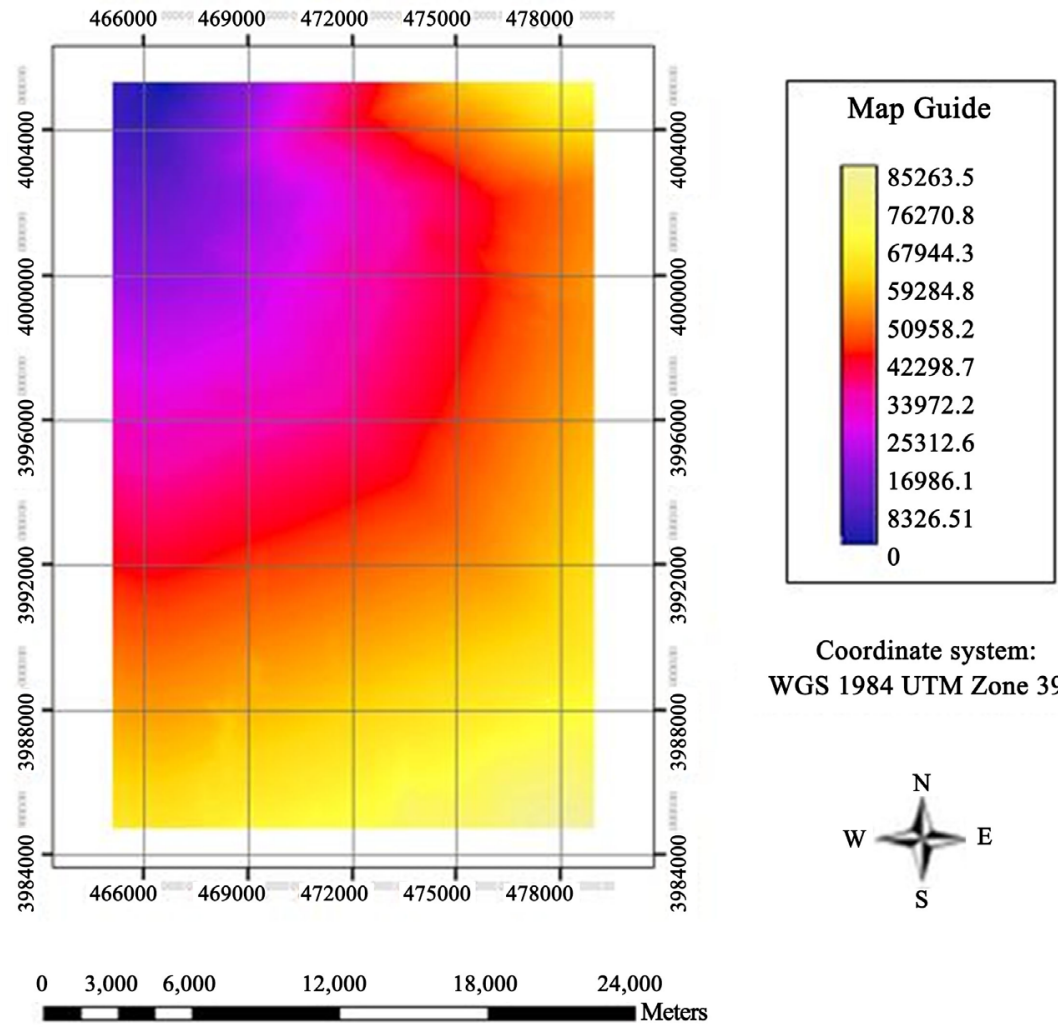

Coordinate system: WGS 1984 UTM Zone 39N<smiles></smiles>

Figure 7. Accumulative cost surface of the study area. 
iii) Determining optimum path: The accumulative cost has been created in previous step, on this stage use to determine the optimum path all points of cost surface. According to Figure 8 at this stage, path finding function start search from endpoints by using window of $3 \times 3$ and then search around each pixel's neighbor and select least accumulative cost pixel for pass and path finding process continue frequently until reach to start point and at last according to Figure 9 optimum path determined.

\begin{tabular}{|c|c|c|c|c|c|c|c|c|c|c|c|c|c|}
\hline $\mathrm{S}$ & & 4 & 2 & 6 & 7 & 9 & 8 & 14.7 & 0.0 & 15.8 & 14.3 & 19.2 & 16.9 \\
\hline & & 9 & 3 & 7 & 8 & 9 & 7 & 11.8 & 10.1 & 14 & 18.6 & 16.4 & 19.7 \\
\hline & & 6 & 4 & 6 & 2 & 6 & 4 & 12.8 & 8.7 & 13.8 & 14.2 & 14.6 & 12.9 \\
\hline & & 5 & 7 & 3 & 5 & 5 & 7 & 11.6 & 14.8 & 6.4 & 8.4 & 8.1 & 17.6 \\
\hline & & 6 & 3 & 9 & 4 & 2 & 9 & 6.8 & 13.6 & 6.5 & 7.6 & 7.5 & 15.0 \\
\hline & $\mathrm{E}$ & 7 & 5 & 5 & 9 & 7 & 8 & 20.8 & 9.7 & 18.6 & 21.8 & 12.2 & 21.7 \\
\hline
\end{tabular}

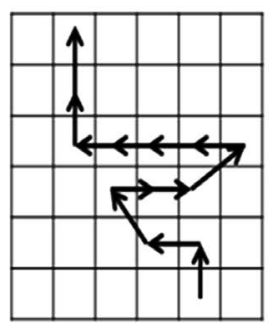

Figure 8. The process of determining the optimum path in raster model.

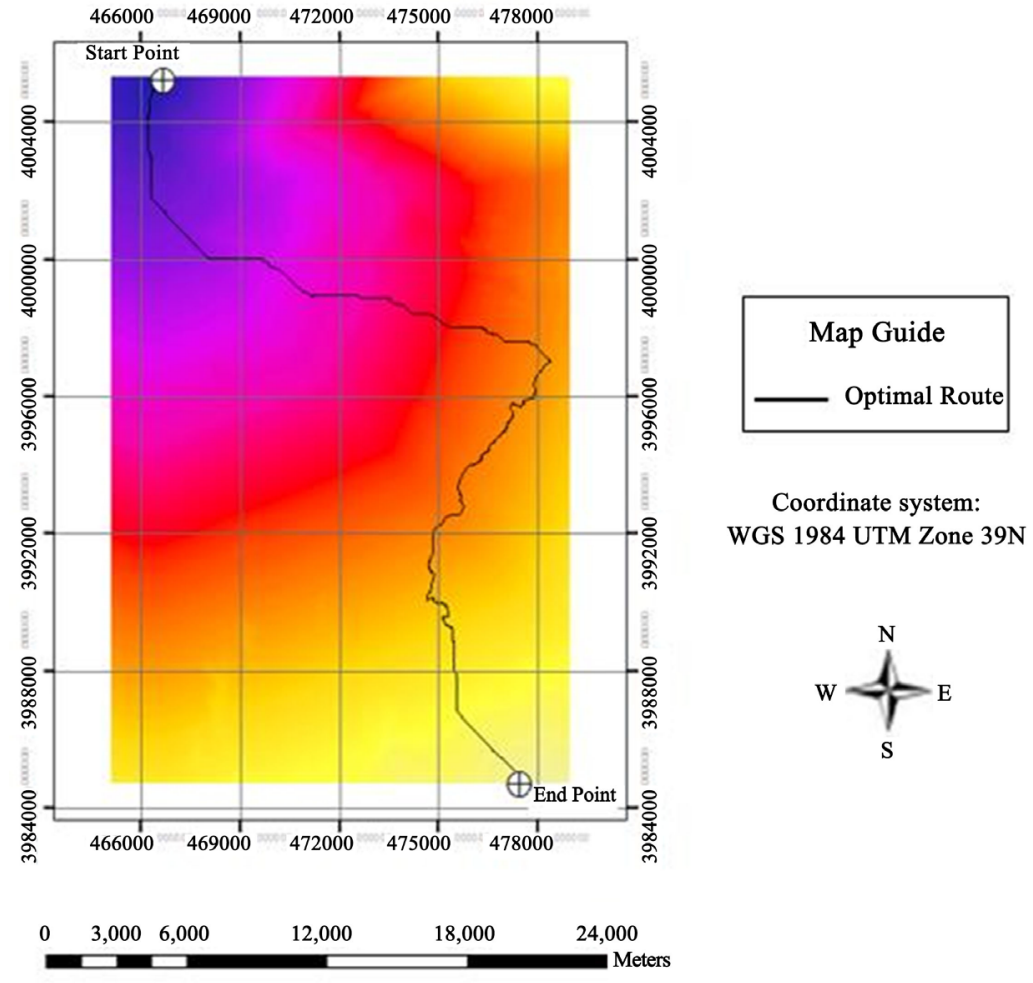

Figure 9. Determination of the optimum path in network GIS. 
After determination of optimum path, the cost analyze result of GIS designed path and Alborz province water and wastewater company path, illustrated on Table 6 and Table 7, as we know the purpose of this research, finding the best path of water transition pipeline by using network and spatial analyzing. Thus, further than GIS analyze a handful of items for facial compare between two paths add to research. Finally, by using pay item of water and road transition field on 2015, which total cost of constructing pipelines for Alborz province water and waste water company and optimum path is $12,975,209,225.08074$ and $11,158,679.932$ respectively.

\section{Conclusions}

Constructing water transition pipelines, one of the most important activities of water and wastewater industry of country which with due to high cost and pipeline environmental interaction effects on the other hand, cause consider several different parameters in this case study and because in path finding process, the parameters are not independent and they have interact and feedbacks together, which necessity to use Multi-Criteria Evaluation (MCE) method as one of the decision support methods in GIS. There for considering these parameters simultaneously could achieve to better output instead of these parameters independent and separately. The result achieved from this study demonstrate the importance of MCE and effect of weighting factors in network method and spatial analyze, so that by ignoring influential factors, cost and exploitation time from pipeline. For this reason, the purpose of research focus on determination optimum path of water transition pipelines from Taleghan's Dam to Hashtgerd New City, by the way tried at first by using analysis capabilities in GIS environment, IDRISI Selva and applying water and wastewater technical section expert's suggestions, optimum path determined.

Then the optimum path and proposed path by Alborz province water and

Table 6. Fiscal analyzing optimum path against alborz province water and wastewater company.

\begin{tabular}{ccccc}
\hline $\begin{array}{c}\text { Pipelines pass expense from land } \\
\text { use (dollar) }\end{array}$ & & & \\
\hline agriculture & garden & agriculture & garden & \\
$10,981,847.2955$ & $3,987.0917$ & $60,039,328$ & 50.862 & Optimum path \\
$6,042,187.886$ & $6,042,187.886$ & $345,968,208$ & $12,311.5176$ & $\begin{array}{c}\text { Alborz province water and wastewater } \\
\text { company }\end{array}$ \\
\hline
\end{tabular}

Table 7. Fiscal analyzing optimum path against alborz province water and wastewater company.

\begin{tabular}{|c|c|c|c|c|c|}
\hline Sum total costs (dollar) & $\begin{array}{l}\text { Destruction price of asphalt cover } \\
\text { because of pipelines intersection with } \\
\text { road (dollar) }\end{array}$ & $\begin{array}{c}\text { Price cut until } 4 \\
\text { depth (dollar) }\end{array}$ & $\begin{array}{l}\text { Total price } \\
\text { (dollar) }\end{array}$ & Length (km) & \\
\hline $11,158,679.932$ & $75,939.5348$ & $32,039.9529$ & $28,982.2315$ & 35 & Optimum path \\
\hline $12,975,209,225.08074$ & $119,601.2646$ & $37,255,691.1377$ & $337,002.0757$ & 40.6976 & $\begin{array}{l}\text { Alborz province water and } \\
\text { wastewater company }\end{array}$ \\
\hline
\end{tabular}


wastewater company compared in technical and engineering, ecological and sumptuary point of view. By comparing two linear schemes imply that expense pf optimum path only by applying influential of some layers increase rather than water and wastewater path. Two path compared based on total cost and show that optimum path rather than water and wastewater path $14 \%$ decrease expense and extra cost mostly due to the more intersection between pipeline with river and road, pass unauthorized areas and personal parcels which need to pay and pass through different land use areas cause to increasing cost and pipeline's length which role main obstacle for execute process while the proposed path achieved from this research executable. In this research, worth of delay time and influence of obstacle factors expressed scientifically and mathematical simplified and prepared for pre-execute.

\section{Recommendations}

As each region has special properties proposed in this research use other method like genetic algorithm for path finding and there for result analyze until best path base of technical and engineering parameters, bio-ecological, sumptuary distinct and execute.

\section{References}

[1] Negahdari, J., Rangzan, K., Ghobadi, M.H. and Vakilian, A.A. (2012) Routing between Hamedan, and Central on the Principles of Environmental Geology Using Remote Sensing, and GIS. Location Mapping Information Journal Advocacy Engineering, 4, 15-26.

[2] Vahed Manshuri, A. (1993) Two-Dimensional Optimization Method. Graduate Studies Thesis Sharif University of Technology.

[3] Naghibi, F. (2005) Optimum Path Finding of Oil and Gas Pipelines by Using Geographical Information System. Thesis (Master), Tehran University, Technical College, Survey Engineering and Geomatics Group.

[4] Shoubiri, G., Rajabi, A. and Keipour, M. (2015) Optimum Path Finding of Water Transition Pipeline by Using Digital Terrain Model and GIS Tool. 5 th International Conference of Construction and Project Management, Tehran, Alaeddole Institute.

[5] Yildrirm, V. and Yomuralioglu, T. (2011) NABACCO Pipeline Path Selection through Turkey, Comparison of a GIS Based Approach to a Traditional Path Selection Approach. Oil, and Gas European Magazine.

[6] Balogun, A.-L., Matori, A.N., Lawal, D.U. and Chandio, I. (2012) Optimal Oil Pipeline Path Selection Using GIS: Community Participation in Weight Derivation, and Disaster Mitigation. ACSIT Press, Singapore.

[7] Ghose, M.K., Dikshit, A.K. and Sharm, S. (2006) A GIS Based Transportation Model for Solid Waste Disposal: A Case Study on Asansol Municipality. Waste Management, 26, 1287-1293. https://doi.org/10.1016/j.wasman.2005.09.022

[8] Rudolph, G. (1994) Convergence Analysis of Canonical Genetic Algorithms. IEEE Transactions on Neural Networks, 5, 96-101. https://doi.org/10.1109/72.265964

[9] Feldman, S.C., Pelletier, R.E., Walser, W.E., Smoot, J.C. and Ahl, D. (1995) A Prototype for Pipeline Routing Using Remotely Sensed Data, and Geographic Informa- 
tion System Analysis. Remote Sensing of Environment, 53, 123-131. https://doi.org/10.1016/0034-4257(95)00047-5

[10] Collischon, W. and Pillar, J.V. (2000) A Direction Dependent Least Cost Path Algorithm for Roads, and Canals. International Journal of Geographic Information System, 12, 491-508.

[11] Cheng, M.Y. and Chang, G.L. (2001) Automating Utility Path Design, and Planning through GIS. Automation in Construction, 10, 507-516. https://doi.org/10.1016/S0926-5805(00)00103-5

[12] Derekenaris, G., Garofalakis, J., Makris, C., Prentzas, J., Sioutas, S. and Tsakalidis, A. (2001) Integrating GIS, GPS, and GSM Technologies for the Effective Management of Ambulances. Computers, Environment and Urban Systems, 25, 267-278. https://doi.org/10.1016/S0198-9715(00)00025-9

[13] Sheu, S.T. and Chuang, Y.R. (2006) A Pipeline-Based Genetic Algorithm Accelerator for Time-Critical Processes in Real-Time Systems Computers. IEEE Transactions on Computers, 55, 1435-1448. https://doi.org/10.1109/TC.2006.171

[14] Hasan, B.S., Khamees, M.A. and Mahmoud, A.S.H. (2007) A Heuristic Genetic Algorithm for the Single Source Shortest Path Problem. Proceedings of the IEEE/ACS International Conference on Computer Systems and Applications, 13-16 May 2007, Amman, 187-194.

[15] Iqbal, M., Sattar, F. and Nawaz, M. (2006) Planning a Least Cost Gas Pipeline Path a GIS, and SDSS Integration Approach. Proceedings of the International Conference on Advances in Space Technologies, 2-3 September 2006, Islamabad, 126-130.

[16] Jun, C., Koo, J. and Koh, J. (2002) Developing a Water Pipe Management System in Seoul using the GIS. Journal of the Korean Society of Civil Engineers, 1, 429-438.

[17] Tarantilis, C.D., Diakoulaki, D. and Kiranoudis, C.T. (2004) Combination of Geographical Information System, and Efficient Path Finding Algorithms for Real Life Distribution Operations. European Journal of Operational Research, 152, 437-453. https://doi.org/10.1016/S0377-2217(03)00035-3

[18] (2016) Statistical Yearbook of Alborz.

[19] Karam, A. (2005) Land Suitability Analysis for Physical Development in the North West of Shiraz Based Approach using Multi Criteria Evaluation in GIS. Geographical Journal, 54, 93-106.

[20] Eastman, J.R. (2006) IDRISI Andes Guide to GIS, and Image Processing. Clark University, Worcester, $328 \mathrm{p}$.

[21] Esri (2016) Spatial Analyst Tutorial.

[22] Malczewski, J. (1999) GIS, and Multi Criteria Decision Analysis. John Wiley \& Sons, Inc., Etobicoke, 392 p.

[23] Tomlin, D. (1999) Geographic Information Systems, and Cartographic Modeling. Prentice-Hall Inc., Hoboken, 119-122.

[24] Stefanakis, E. and Kavouras, M. (1995) Determination of the Optimum Path on the Earth Surface. Proceedings of 17 th International Cartographic Association Conference, Barcelona, 3-9 September 1995, 268-282.

[25] Douglas, D.H. (1994) Least Cost Path in GIS using Accumulated Cost Surface, and Slopeline. Cartographica, 3, 37-51. 